\title{
Landscape complexity and farmland biodiversity: Evaluating the CAP target on natural elements
}

\author{
A. Cormont ${ }^{a}, *$, H. Siepel $^{\mathrm{b}, \mathrm{c}}$, J. Clement $^{\mathrm{a}}$, T.C.P. Melman ${ }^{\mathrm{a}}$, M.F. WallisDeVries ${ }^{\mathrm{d}, \mathrm{e}}$, \\ C.A.M. van Turnhout ${ }^{\mathrm{f}}$, L.B. Sparrius ${ }^{\mathrm{g}}$, M. Reemer ${ }^{\mathrm{h}, \mathrm{i}}$, J.C. Biesmeijer ${ }^{\mathrm{i}, \mathrm{j}}$, F. Berendse ${ }^{\mathrm{b}}$, \\ G.R. de Snoo ${ }^{\mathrm{b}, \mathrm{k}}$ \\ a Alterra, Wageningen University E Research Centre, P.O. Box 47, 6700 AA Wageningen, The Netherlands \\ ${ }^{\mathrm{b}}$ Nature Conservation and Plant Ecology Group, Wageningen University, P.O. Box 8031, 6700 EH Wageningen, The Netherlands \\ ${ }^{\mathrm{c}}$ Animal ecology and ecophysiology, Institute for Water and Wetland Research, Radboud University Nijmegen, P.O. Box 9010, 6500 GL Nijmegen, The \\ Netherlands \\ ${ }^{\mathrm{d}}$ Laboratory of Entomology, Wageningen University, P.O. Box 47, 6700 AA Wageningen, The Netherlands \\ e De Vlinderstichting/Dutch Butterfly Conservation, P.O. Box 506, 6700 AM Wageningen, The Netherlands \\ f SOVON, Dutch Centre for Field Ornithology, Toernooiveld 1, 6525 ED Nijmegen, The Netherlands \\ FLORON, Floristisch Onderzoek Nederland, Toernooiveld 1, 6525 ED Nijmegen, The Netherlands \\ h EIS-Nederland, Postbus 9517, 2300 RA Leiden, The Netherlands \\ i Naturalis Biodiversity Center, Darwinweg 2, 2333 CR Leiden, The Netherlands \\ ${ }^{\mathrm{j}}$ Institute for Biodiversity and Ecosystem Dynamics (IBED), Universtiy of Amsterdam, P.O. Box 94248, 1090 GE Amsterdam, The Netherlands \\ ${ }^{\mathrm{k}}$ Faculty of Science, Leiden University, Einsteinweg 55, 2333 CC Leiden, The Netherlands
}

\section{A R T I C L E I N F O}

\section{Article history:}

Received 4 June 2015

Received in revised form

13 November 2015

Accepted 17 December 2015

\section{Keywords:}

Common Agricultural Policy

Ecological focus area

Farmland biodiversity

Landscape complexity

Species richness

\begin{abstract}
A B S T R A C T
Increasing pressures on natural areas and limited conservation budgets require, particularly in rural landscapes in the Western world, an immediate answer to the question how much natural area is required to provide a sustainable future for wild plant and animal species on farmland. The European Union proposed in its Common Agricultural Policy that 3-7\% of EU farmland should be managed as ecological focus area (EFA) in order to halt biodiversity loss. For the first time, we empirically assessed the implications of this policy by evaluating the effects of the density of natural elements in agricultural landscapes on multi-taxon species richness, including vascular plants, breeding birds, butterflies, hoverflies, dragonflies, and grasshoppers for an entire European country. We found that species richness increased either as linear or as a logarithmic function of the proportion of natural elements in the landscape, but not with a sigmoid function as predicted by the 'intermediate landscape complexity' hypothesis. Even landscapes with $3-7 \%$ of natural elements harboured generally $37-75 \%$ of maximum species richness, indicating good potential of implementing the CAP target to preserve farmland biodiversity. However, differences between the 3 and $7 \%$ limits were considerable for butterflies, birds, and hoverflies. Also, the shape of the species richness response was shown to differ between landscape types for butterflies. Thus, it may be necessary to develop tailor-made guidelines at regional levels.
\end{abstract}

(C) 2015 Elsevier GmbH. All rights reserved.

\footnotetext{
* Corresponding author.

E-mail addresses: anouk.cormont@wur.nl (A. Cormont), henk.siepel@wur.nl (H. Siepel), jan.clement@wur.nl (J. Clement), dick.melman@wur.nl (T.C.P. Melman), michiel.wallisdevries@vlinderstichting.nl (M.F. WallisDeVries), chris.vanturnhout@sovon.nl (C.A.M. van Turnhout), sparrius@floron.nl (L.B. Sparrius), menno.reemer@naturalis.nl (M. Reemer), koos.biesmeijer@naturalis.nl (J.C. Biesmeijer), frank.berendse@wur.nl (F. Berendse), g.r.desnoo@science.leidenuniv.nl (G.R. de Snoo).
}

\section{Introduction}

The impacts of anthropogenic activities and economic development have resulted in worldwide modification, destruction and fragmentation of our natural environment (Hanski, 2005). As a consequence, biodiversity is disappearing at an alarming rate and the target to halt biodiversity loss is still far from being met (CBD, 2010). This is particularly relevant for agricultural landscapes, where biodiversity is under severe pressure from intensive land use practices but is needed for pollination, pest control and other ecosystem services (Tscharntke, Clough et al., 2012). In Europe, habitats linked to agro-ecosystems have the worst conservation status of all ecosys- 
tems (European Environment Agency, 2010; Pe'er et al., 2014). The increasing pressure on remaining natural areas and limited conservation budgets invoke the need for scientific underpinning of policies on the amount of natural elements needed for biodiversity preservation, especially when this nature is interwoven with other land use forms such as agriculture (Batáry, Báldi, Kleijn, \& Tscharntke, 2011; Martinez, Ramil, \& Chuvieco, 2010; Stoate et al., 2009). Moreover, spatial targeting (Teillard et al., 2012) of conservation measures would help to provide positive biodiversity effects at lower costs (Van Teeffelen \& Moilanen, 2008).

Thus far, the Common Agricultural Policy (CAP) of the European Union (EU) has not been successful in preserving farmland biodiversity (Pe'er et al., 2014). Increasing intensification (e.g. increasing farm sizes, increasing fertilizer use), subsidized by the CAP, has together with e.g. land abandonment, lead to a continuing decline of farmland biodiversity (Carvalheiro et al., 2013; Pe'er et al., 2014). In the reform of the CAP, a general, non-spatially targeted density metric is assigned to be implemented as a 'green payment' measure under Pillar 1: 3-5\% of EU farmland should be managed as ecological focus areas in order to halt biodiversity loss, to be increased to $7 \%$ by 2017 (EC, 2013). Such ecological focus areas could include land left fallow, terraces, buffer strips and afforested areas. These areas should provide sufficient habitat for wild plant and animal species and should facilitate dispersal of species across the landscape (EC, 2010). Agri-environment schemes (AES), subsidy arrangements designed to encourage EU farmers to protect and enhance the farmland environment (Teillard et al., 2012), can be implemented to achieve this requirement. However, evidence is lacking that application of the 3-7\% guideline will actually result in an effective preservation or restoration of farmland biodiversity. According to the 'intermediate landscape complexity hypothesis' by Tscharntke, Tylianakis et al. (2012), species richness should increase according to a sigmoid curve as function of landscape complexity, i.e., the availability of natural elements in the landscape. This implies a lesser effectiveness of agri-environment schemes in landscapes with either a low or a high cover of natural elements. It is of paramount importance to know if this hypothesis applies to current agricultural landscapes, because it determines the usefulness of an EU-wide implementation of the 3-7\% policy guideline. Thus, what will be the implications of this policy regarding farmland biodiversity?
In this study, we used high-resolution data on land use and species occurrence across a range of taxonomic groups to provide a first glance of the potential significance of the 3-7\% policy guideline for the preservation of farmland species richness. To do so, we analysed the functional relationship between the percentage of natural elements in the landscape, i.e., land not used for agricultural production and the species richness of vascular plants, breeding birds, butterflies, hoverflies, dragonflies, and grasshoppers in the Netherlands. These relationships were then used to assess to what extent the 3-7\% CAP guideline may accommodate farmland biodiversity. We assume that if a density of $3-7 \%$ of natural elements in a square kilometre grid indeed accommodates farmland biodiversity well, the same holds true for a similar percentage of EFA on single farms. In order to test the applicability of the results in different regions, we also investigated whether the response of species richness to the availability of natural elements differed between landscape types.

\section{Methods}

\subsection{Nature element map}

To estimate landscape complexity, we created a new, highly detailed nature element map of the Netherlands, including all natural elements of the country. We did this by combining a 1:10,000 topographical map (Top10NL 2010), two land use maps (Bestand Bodemgebruik 2008 and Landgebruik Nederland 6), and a nature type map (Basiskaart Natuur 2009). From these maps, 50 nature element types could be identified, that we represented as $2.5 \times 2.5 \mathrm{~m}$ grid cells on our nature element map (for an overview of the nature elements, see Appendix A). The mapped elements include both polygon-shaped landscape elements (e.g. forests, heathlands, wetlands) and line-shaped landscape elements (e.g. hedgerows, ditches; see Appendix A), and woody (e.g. forests, hedgerows), herbaceous (e.g. heathlands, road verges, dry ditches) and wetland (e.g. wetlands, ditches) elements. For some natural elements (e.g. dry ditches in natural, agricultural or urban surroundings), we combined the information from different source maps, so that the embedding of the elements became clear. This information was used to distinguish potential habitat for the different taxonomic groups (see Appendix A). To identify woody farmyard vegetation,

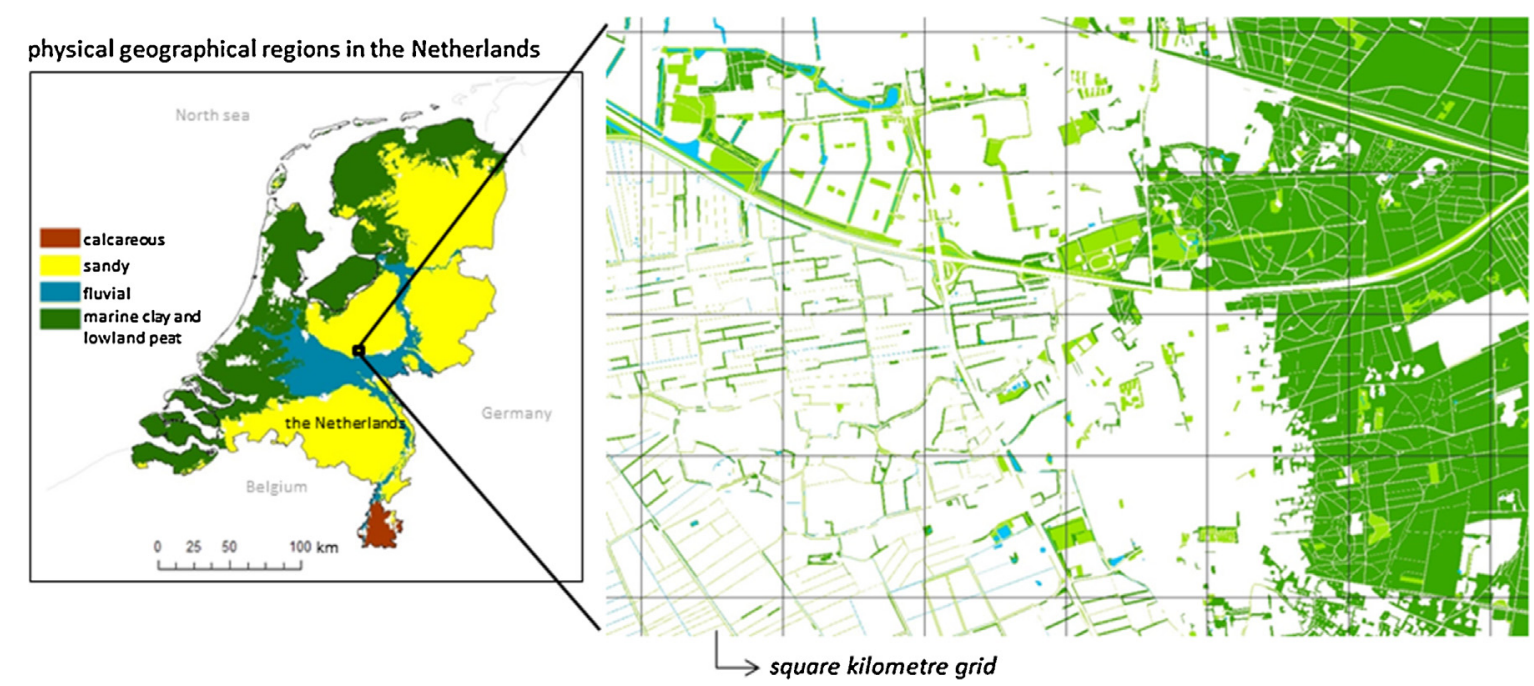

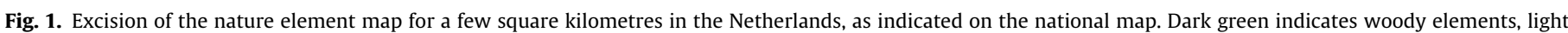

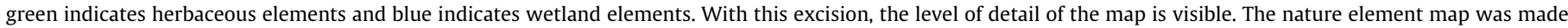

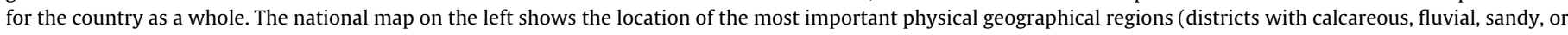
marine clay and lowland peat soils). 


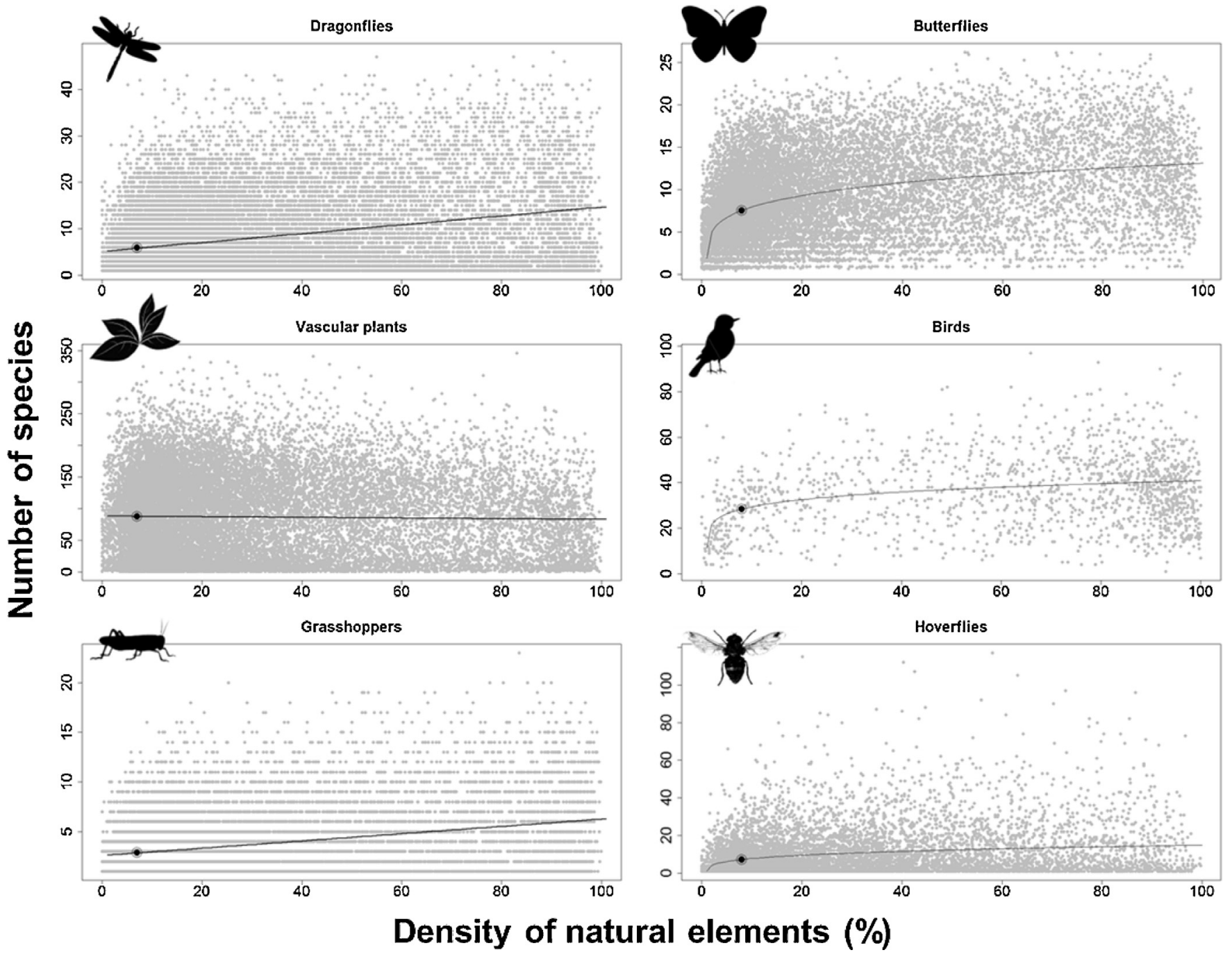

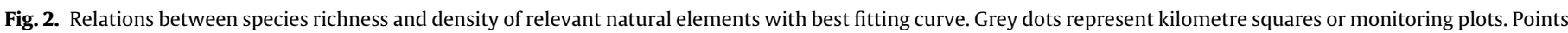
on the fitted curves indicate $7 \%$ of natural elements.

we used a digital elevation map (Actueel Hoogtebestand Nederland) to assess the cover of tree crowns within farmyards.

\subsection{Species data}

In the Netherlands, long-term, multi-species and country-wide species distribution data are available for many taxonomic groups (e.g. invertebrates (Kleukers, Van Nieukerken, Odé, Willemse, \& Van Wingerden, 1997; Nederlandse Vereniging voor Libellenstudie 2002; Reemer et al., 2009; Van Swaay, Nowicki, Settele, \& van Strien, 2008), breeding birds (Van Dijk, 2004; Van Turnhout, Foppen, Leuven, Van Strien, \& Siepel, 2010), plants (Van der Meijden et al., 1996)). Of all species groups, we chose to include vascular plant, breeding bird, butterfly, hoverfly, dragonfly, and grasshopper species in our analyses, since the occurrence of the species within these groups have been investigated most thoroughly throughout the whole country. Only potential farmland species were considered and selected based on expert judgement. This includes species from semi-natural communities, but excludes rare species and vagrants, as these would bias the analysis. Using the presence of species per species group since 2000 , we extracted species richness per square kilometre for vascular plants and invertebrates and per monitoring plot (with an area of 10-500 ha each) for breeding birds.
For vascular plants, distribution data were provided by FLORON from the National Database of Flora and Fauna (NDFF). We considered only those square kilometres that we supposed to be well-monitored (i.e., at least four observations of a species in at least four different years).

For distribution data on grasshoppers, hoverflies and dragonflies, we used the Database of the European Invertebrate Survey of the Netherlands. For butterflies, we used data from the NDFF on derived estimates of butterfly occupancy (see for method Van Strien et al. (2013)) of Dutch Butterfly Conservation. We considered only those square kilometres that we supposed to be well-monitored (i.e., at least four observations of a species over the period 2000-2010). Occupancy probabilities per square kilometre were summed for all butterfly species per nature element type as a measure of species richness. For Brown Hairstreak (Thecla betulae) and Purple Emperor (Apatura iris), no occupancy chances were calculated. For these species, presences per square kilometre were added as 1 to the summed occupancy chances for these square kilometres.

Breeding bird monitoring in the Netherlands is coordinated by SOVON (Dutch Centre for Field Ornithology). Every year, plots of varying size (10-500 ha each) are visited to assess the number of territories of all breeding bird species present (Van Dijk, 2004). We 
Table 1

Best fitting curves for relations between species richness and density of relevant natural elements for all species groups.

\begin{tabular}{|c|c|c|c|c|c|c|c|c|}
\hline \multirow[t]{2}{*}{ Species group } & \multirow[t]{2}{*}{ Equation } & \multicolumn{3}{|c|}{ Model summary } & \multicolumn{2}{|c|}{ Parametre estimates } & \multicolumn{2}{|c|}{$\begin{array}{l}\text { Model fit in respect to } 100 \% \\
\text { density of nature elements }\end{array}$} \\
\hline & & $R$ square & $F$ & $n$ & Constant & b1 & At $3 \%$ density (in $\%$ ) & At $7 \%$ density (in\%) \\
\hline Dragonflies & Linear & 0.095 & 2342.519 & 22271 & 5.224 & 0.095 & 37 & 40 \\
\hline Vascular plants & Linear & 0 & 9.065 & 20282 & 88.36 & -0.054 & 106 & 106 \\
\hline Grasshoppers & Linear & 0.095 & 1528.17 & 14501 & 2.623 & 0.037 & 43 & 46 \\
\hline Butterflies & Logarithmic & 0.178 & 3173.057 & 14689 & 4.54 & 1.691 & 52 & 64 \\
\hline Birds & Logarithmic & 0.062 & 96.078 & 1449 & 20.963 & 3.757 & 66 & 74 \\
\hline Hoverflies & Logarithmic & 0.043 & 359.102 & 8007 & 3.091 & 2.304 & 41 & 55 \\
\hline
\end{tabular}

Sign.<0.001. except for vascular plants $(0.003)$

summed the species that were observed as breeding during the period 2000-2010 per monitoring plot.

\subsection{Statistical analyses}

With stepwise regressions with forward selection procedure using R 2.12.2 software (Ihaka \& Gentleman, 1996), we correlated species richness per taxonomic group to the surface areas of the different natural element types per square $\mathrm{km}$ or monitoring plot. In this way, we selected the collection of nature elements of which the surface areas per square $\mathrm{km}$ (densities) related significantly to species richness. This prevented possible bias from nature elements occupying large areas but not supporting the diversity in the taxonomic group included. Subsequently, for each taxonomic group we summed the surface areas of only those nature elements that had significant effects on the diversity within that group. By dividing the summed areas by square $\mathrm{km}$ or by monitoring plot size, we obtained the density of natural elements per square km or monitoring plot. We created plots of density of natural elements against species richness per taxonomic group and sought for the best fit using curve estimation with linear, logarithmic and sigmoid shaped curves in SPSS. Since breeding bird monitoring plots differ in size, we corrected for plot size here by adding it as a covariate to the fitted models. We did not correct for the effect of observation intensity (number of years that a plot was monitored) on number of species $\left(R^{2}=0.07\right)$. We repeated the procedure of stepwise regression and curve fitting for butterfly data in square kilometres located within specific physical geographical regions (Schouten et al., 2009) (districts with calcareous, fluvial, sandy, or marine clay and lowland peat soils-see Fig. 1) to look for the effect of landscape type on the relation between species richness and density of natural elements. We executed this regional analyses only with butterfly data as an example, as this data covers the square $\mathrm{kms}$ in the country most nicely. To be able to relate our results to the CAP norms, we specified the model fits at 3 and $7 \%$ density of natural elements and put both values in respect to the species richness at $100 \%$ density (whole grid cell occupied with nature).

\section{Results}

For invertebrates and plant species richness, the most relevant nature elements resulting from the stepwise regression analyses are line-shaped elements such as hedgerows, (dry) ditches and water banks and small landscape elements such as farmyard vegetation. For breeding birds, highest species richness was observed in monitoring plots that mainly consist of deciduous and mixed forests, extensively managed grassland, herbaceous dune vegetation, heathlands or wetlands.

Plotting species richness against density of relevant natural elements results in scattered patterns due to the high number and variety of square $\mathrm{km}$ or monitoring plots (Fig. 2). Most square kilometres comprise between 0 and $20 \%$ of natural elements, while

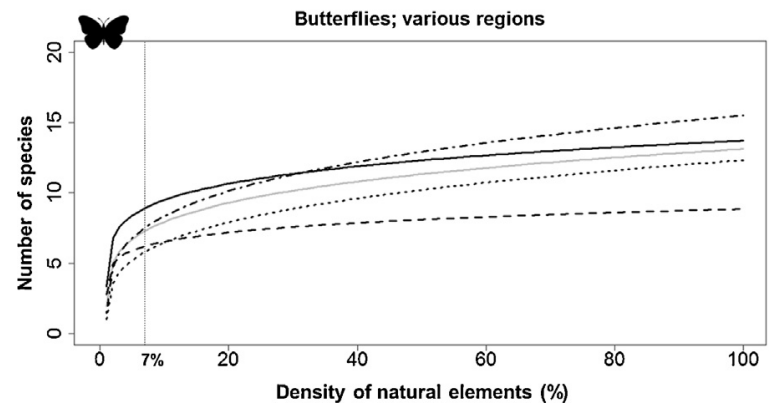

Fig. 3. Best fitting curves for relations between butterfly species richness and density of relevant natural elements within specific physical geographical regions and the country as a whole. Grey solid line: country as a whole; black solid line: sandy soils; dashed line: marine clay and lowland peat soils; dotted line: fluvial soils; dotdashed line: calcareous soils. Vertical line indicates $7 \%$ of natural elements.

most monitoring plots (birds) contain between 80 and $100 \%$, as can be seen from the scatter density in Fig. 2 (see also frequency graphs in Appendix B).

For dragonflies, vascular plants and grasshoppers, we found a linear curve to be best fitting the relationship between density of natural elements and species richness. A logarithmic curve best described the response for butterflies, birds and hoverflies. For most species groups, the differences in $R^{2}$ for linear and logarithmic curve fits were minor, while sigmoid curves fitted less well in all cases. In general, the best fits show an increase in species richness with increasing densities of natural elements (except for vascular plants, b1 $=-0.054)$. However, for logarithmic fits, this increase in species richness is highest at relatively low densities. The rate of increase varies amongst species groups (Table 1). Hoverflies show the strongest increase between 3 and 7\% densities. At 7\% density of natural elements, the number of bird species however is already $74 \%$ of the fitted value for monitoring plots comprising completely of nature. On the other hand, for dragonflies this is only $40 \%$.

Zooming in at regional level, the rate of increase of species richness with density of natural elements varies amongst landscape types for butterflies. The number of butterfly species increases relatively strongly in calcareous and fluvial districts for densities larger than $7 \%$, compared to other regions and the country as a whole (Fig. 3, Table 2)

\section{Discussion}

We found that species richness increased either as linear or as a logarithmic function of the proportion of natural elements in the landscape, but not with a sigmoid function as predicted by the 'intermediate landscape complexity' hypothesis. The absence of the left part of the sigmoid curve cannot be explained by a monitoring bias to more complex areas, as we took only wellstudied square km's and monitoring plots into consideration. A likely explanation would rather be the percentage of non-crop area, 
Table 2

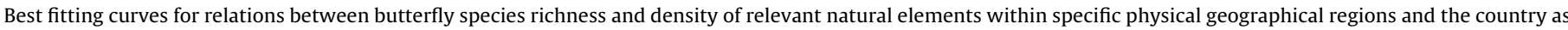
a whole. All curves are logarithmic.

\begin{tabular}{|c|c|c|c|c|c|c|c|c|}
\hline \multirow[t]{2}{*}{ Region } & \multicolumn{4}{|c|}{ Model summary } & \multicolumn{2}{|c|}{ Parametre estimates } & \multicolumn{2}{|c|}{$\begin{array}{l}\text { Model fit in respect to } 100 \% \\
\text { density of nature elements }\end{array}$} \\
\hline & $R$ square & $F$ & $n$ & Share of total country area (in\%) & Constant & b1 & At $3 \%$ density (in $\%$ ) & At $7 \%$ density (in $\%$ ) \\
\hline Marine clay \& peaty & 0.083 & 368.968 & 3232 & 28 & 4.888 & 0.79 & 68 & 75 \\
\hline Fluvial & 0.154 & 248.102 & 1362 & 9 & 3.212 & 1.605 & 47 & 60 \\
\hline Sandy & 0.101 & 799.662 & 7104 & 48 & 6.02 & 1.612 & 58 & 68 \\
\hline Total country & 0.178 & 3173.057 & 14689 & 100 & 4.54 & 1.691 & 52 & 64 \\
\hline Calcareous & 0.222 & 93.842 & 331 & 2 & 4.55 & 1.929 & 50 & 62 \\
\hline
\end{tabular}

Equations: logarithmic; sign. $<0.001$

that is related to landscape complexity, as indicated by Tscharntke, Tylianakis et al. (2012). This relationship may vary greatly depending on where you are in the world. The 'intermediate landscape complexity' hypothesis was designed for Central Europe and thus not for the Netherlands. Unlike the Netherlands, Central Europe can regionally be characterized by extensive areas of cultural land with only cropped area, 'cleared' from any nature. In the Netherlands, about 66 thousand agricultural holdings manage about 20 thousand square $\mathrm{kms}$ of land, of which $92 \%$ is utilized as agricultural area-the rest of the farms' lands are occupied by nature, stables and farmyards (CBS, 2015). In Germany for example, the utilized agricultural area per farm is almost twice as large as in the Netherlands (Eurostat, 2015). This might explain the absence of the left part of the sigmoid curve in our curve fits for the Netherlands, that would otherwise result from purely 'cleared landscapes' like in Central Europe.

We investigated landscape complexity within the borders of the spatial monitoring units (square kilometre or monitoring plots). Since the home range of specific species can be larger than such a unit, it is relevant to consider landscape complexity in a wider spatial context. We tested the effect of considering such a wider spatial context for butterfly species of woody and herbaceous vegetation (all shapes of nature elements, whole country considered). Butterfly data is well-suited for such an analysis, since the species occupy clear home ranges. Based on the average home ranges, we considered landscape complexities in the $5 \times 5 \mathrm{~km}$ grids surrounding the focal monitoring squares. We did not find notable differences compared to the findings considering landscape complexity within the borders of the monitoring kilometre squares.

Our analyses focus on assessing the importance of the density of natural elements for species richness across several taxonomic groups. Often, higher numbers of species have been found in areas with a higher diversity of habitats (MacArthur, 1965; Shmida \& Wilson, 1985), although this may mean that these are sites with a high degree of habitat fragmentation. However, as long as these fragments are relevant according to the stepwise analyses (correlation between species richness and surface areas of natural element types), we summed the areas and these may still comprise to a high density of natural elements.

For halting biodiversity loss it is necessary to prevent population declines. Our analyses focus on species richness as this is the most direct measure to assess the possible effect of EFA's on the prevention of biodiversity loss. However, we did not account for abundance, thus it is possible that the natural elements that were selected to account for a high species richness may not be the best to support large population sizes of each individual species. Hence, as a next step to assess the implications of the CAP measures, available abundance data could be used to support our species richness analyses. Especially rare habitat specialists may be associated with sites with poor species richness (Duelli \& Obrist, 2003; Prendergast, Quinn, Lawton, Eversham, \& Gibbons, 1993). Focussing our analyses on species richness of rare species only would however result in too low species numbers per spatial monitoring unit to retrieve significant results.

We found that even landscapes with 3-7\% of natural elements harboured generally $37-75 \%$ of maximum species richness, indicating good potential of implementing the CAP target to preserve farmland biodiversity. However, differences between the 3 and $7 \%$ limits were considerable for butterflies, birds, and hoverflies. Also, the shape of the species richness response was shown to differ between landscape types for butterflies. That means that the one-size-fits-all, non-spatially targeted density metric as assigned by the CAP to be implemented by European farmers will not be effective in all situations. Batáry et al. (2011) also states that these approaches are not a very efficient way of spending the limited funds available for biodiversity conservation on farmland. As earlier indicated (Teillard et al., 2012), cost-effective biodiversity conservation measures should focus on nature elements that are relevant to those species and in those situations where the amount and diversity of nature elements is still insufficient. Hence, the only effective conservation strategy will be the development of tailormade guidelines based on region-specific analyses. The guidelines should be targeted to the landscape types of the regions in which they are implemented (Batáry et al., 2011; Whittingham et al., 2007) and the type of species groups at which they are targeted. This could imply that locally more than $7 \%$ of the arable land should be designated, while in other regions a smaller percentage might be sufficient. We suggest to take the percentage for the most critical focal species group as a minimum.

\section{Acknowledgements}

This research is part of the KBIV strategic research programme "Sustainable spatial development of ecosystems, landscapes, seas and regions" which is funded by the Dutch Ministry of Economic Affairs, and carried out by Alterra, Wageningen University \& Research Centre. We thank Paul Goedhart for his advice on statistics. We are grateful to the thousands of observers who gathered vascular plant, breeding bird, butterfly, and grasshopper data in the past decennium, organised by coordinators of FLORON, SOVON, Dutch Butterfly Conservation, and the European Invertebrate Survey - without their efforts this research would not have been possible.

\section{Appendix A.}

Table A1.

\section{Appendix B.}

Fig. A1. 
Table A1

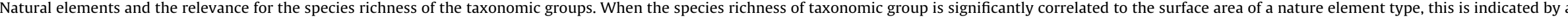
" $\mathrm{X}$ " in the table.

\begin{tabular}{|c|c|c|c|c|c|c|c|c|}
\hline Natural element & Birds & Dragonflies & Grasshoppers & Hoverflies & Vascular plants & Butterflies & Element shape & Vegetation type \\
\hline Agricultural field with special management for meadow birds & & $\mathrm{x}$ & $\mathrm{x}$ & $\mathrm{x}$ & $\mathrm{x}$ & & & \\
\hline Coniferous forest & $\mathrm{x}$ & $\mathrm{x}$ & $\mathrm{x}$ & $\mathrm{x}$ & $\mathrm{x}$ & $\mathrm{x}$ & Polygon & Woody \\
\hline Coniferous forest $<1 \mathrm{ha}$ & & $\mathrm{x}$ & $\mathrm{x}$ & $\mathrm{x}$ & $\mathrm{x}$ & & & \\
\hline Coniferous forest on sandy soil & $\mathrm{x}$ & & $\mathrm{x}$ & $\mathrm{x}$ & $\mathrm{x}$ & & & \\
\hline Coniferous forest on sandy soil $<1$ ha & $\mathrm{x}$ & & $\mathrm{x}$ & $\mathrm{x}$ & $\hat{x}$ & $\mathrm{x}$ & Polygon & Woody \\
\hline Deciduous forest & $\mathrm{x}$ & $\mathrm{x}$ & $\mathrm{x}$ & $\mathrm{x}$ & $\mathrm{x}$ & $\mathrm{x}$ & Polygon & Woody \\
\hline Deciduous forest $<1 \mathrm{ha}$ & & & & & & $\mathrm{x}$ & Polygon & Woody \\
\hline Deciduous forest on sandy soil & $\mathrm{x}$ & $\mathrm{x}$ & $\mathrm{x}$ & $\mathrm{x}$ & $\mathrm{x}$ & $\mathrm{x}$ & Polygon & Woody \\
\hline Deciduous forest on sandy soil $<1$ ha & $\mathrm{x}$ & $\mathrm{x}$ & $\mathrm{x}$ & $\mathrm{x}$ & $\mathrm{x}$ & $\mathrm{x}$ & Polygon & Woody \\
\hline Ditch in agricultural surroundings & $\mathrm{x}$ & $\mathrm{x}$ & $\mathrm{x}$ & $\mathrm{x}$ & $\mathrm{x}$ & & & \\
\hline Ditch in natural surroundings & $\mathrm{x}$ & $\mathrm{x}$ & $\mathrm{x}$ & $\mathrm{x}$ & $\mathrm{x}$ & & & \\
\hline Ditch in urban surroundings & & $\mathrm{x}$ & $\mathrm{x}$ & $\mathrm{x}$ & $\mathrm{x}$ & & & \\
\hline Dry ditch along farm yards & $\mathrm{x}$ & $\mathrm{x}$ & $\mathrm{x}$ & $\mathrm{x}$ & $\mathrm{x}$ & $\mathrm{x}$ & Line & Herbaceous \\
\hline Dry ditch along paved road & $\mathrm{x}$ & $\mathrm{x}$ & $\mathrm{x}$ & $\mathrm{x}$ & $\mathrm{x}$ & $\mathrm{x}$ & Line & Herbaceous \\
\hline Dry ditch along unpaved road & $\mathrm{x}$ & $\mathrm{x}$ & & $\mathrm{x}$ & $\mathrm{x}$ & $\mathrm{x}$ & Line & Herbaceous \\
\hline Dry ditch amongst agricultural fields & $\mathrm{x}$ & & $\mathrm{x}$ & $\mathrm{x}$ & $\mathrm{x}$ & $\mathrm{x}$ & Line & Herbaceous \\
\hline Dry ditch amongst agricultural fields with nature reserve management & $\mathrm{x}$ & $\mathrm{x}$ & & $\mathrm{x}$ & $\mathrm{x}$ & $\mathrm{x}$ & Line & Herbaceous \\
\hline Dry ditch amongst agricultural fields with special management for meadow birds & & $\mathrm{x}$ & $\mathrm{x}$ & $\mathrm{x}$ & $\mathrm{x}$ & & & \\
\hline $\begin{array}{l}\text { Dry ditch amongst extensively managed grasslands } \\
\text { D. }\end{array}$ & $\mathrm{x}$ & $\mathrm{x}$ & $\mathrm{x}$ & & $\mathrm{x}$ & $\mathrm{x}$ & Line & Herbaceous \\
\hline Dry ditch amongst grasslands with special management for meadow birds & & $\mathrm{x}$ & & $\mathrm{x}$ & $\mathrm{x}$ & $\mathrm{x}$ & Line & Herbaceous \\
\hline Dry ditch amongst meadows & & & & & $\mathrm{x}$ & & & \\
\hline Dry ditch amongst production meadows & $\mathrm{x}$ & $\mathrm{x}$ & $\mathrm{x}$ & $\mathrm{x}$ & $\mathrm{x}$ & $\mathrm{x}$ & Line & Herbaceous \\
\hline Dry ditch in heathland & & $\mathrm{x}$ & & & $\mathrm{x}$ & $\mathrm{x}$ & Line & Herbaceous \\
\hline Dry ditch in urban surroundings & & $\mathrm{x}$ & $\mathrm{x}$ & $\mathrm{x}$ & $\mathrm{x}$ & $\mathrm{x}$ & Line & Herbaceous \\
\hline Extensively managed grassland & $\mathrm{x}$ & $\mathrm{x}$ & $\mathrm{x}$ & $\mathrm{x}$ & $\mathrm{x}$ & $\mathrm{x}$ & Polygon & Herbaceous \\
\hline Farm yard vegetation & & $\mathrm{x}$ & $\mathrm{x}$ & & $\mathrm{x}$ & & & \\
\hline Grass in wetland area & $\mathrm{x}$ & $\mathrm{x}$ & & & $\mathrm{x}$ & & & \\
\hline Grassland with special management for meadow birds & $\mathrm{x}$ & $\mathrm{x}$ & $\mathrm{x}$ & $\mathrm{x}$ & $\mathrm{x}$ & $\mathrm{x}$ & Polygon & Herbaceous \\
\hline Grassy road verge & & $\mathrm{x}$ & $\mathrm{x}$ & & $\mathrm{x}$ & $\mathrm{x}$ & Line & Herbaceous \\
\hline Heathland & & & & $\mathrm{x}$ & $\mathrm{x}$ & & & \\
\hline Heathland in dune surroundings & & & & $\mathrm{x}$ & $\mathrm{x}$ & & & \\
\hline Heathland on sandy soil & $\mathrm{x}$ & $\mathrm{x}$ & $\mathrm{x}$ & & $\mathrm{x}$ & $\mathrm{X}$ & Polygon & Herbaceous \\
\hline Heavily grass-encroached heathland & $\mathrm{x}$ & $\mathrm{x}$ & $\mathrm{x}$ & $\mathrm{x}$ & $\mathrm{x}$ & $\mathrm{x}$ & Polygon & Herbaceous \\
\hline Hedgerow in agricultural surroundings & $\mathrm{x}$ & $\mathrm{x}$ & $\mathrm{x}$ & $\mathrm{x}$ & $\mathrm{x}$ & $\mathrm{x}$ & Line & Woody \\
\hline Hedgerow in natural surroundings & $\mathrm{x}$ & $\mathrm{x}$ & $\mathrm{x}$ & $\mathrm{x}$ & & & & \\
\hline Hedgerow in urban surroundings & & $\mathrm{x}$ & $\mathrm{x}$ & $\mathrm{x}$ & $\mathrm{x}$ & $\mathrm{x}$ & Line & Woody \\
\hline Marshland & $\mathrm{x}$ & $\mathrm{x}$ & $\mathrm{x}$ & $\mathrm{x}$ & $\mathrm{x}$ & & & \\
\hline Mixed forest & $\mathrm{x}$ & $\mathrm{x}$ & $\mathrm{x}$ & $\mathrm{x}$ & $\mathrm{x}$ & $\mathrm{x}$ & Polygon & Woody \\
\hline Mixed forest $<1$ ha & $\mathrm{x}$ & & & $\mathrm{x}$ & $\mathrm{x}$ & & & \\
\hline Other water elements (e.g. ponds) in agricultural surroundings & $\mathrm{x}$ & $\mathrm{x}$ & $\mathrm{x}$ & $\mathrm{x}$ & $\mathrm{x}$ & & & \\
\hline Other water elements (e.g. ponds) in natural surroundings & $\mathrm{x}$ & $\mathrm{x}$ & $\mathrm{x}$ & $\mathrm{x}$ & $\mathrm{x}$ & & & \\
\hline Other water elements (e.g. ponds) in urban surroundings & & $\mathrm{x}$ & $\mathrm{x}$ & $\mathrm{x}$ & $\mathrm{x}$ & & & \\
\hline Partly grass-encroached heathland & & $\mathrm{x}$ & $\mathrm{x}$ & & $\mathrm{x}$ & $\mathrm{x}$ & Polygon & Herbaceous \\
\hline Poplar plantation & $\mathrm{x}$ & $\mathrm{x}$ & $\mathrm{x}$ & & $\mathrm{x}$ & $\mathrm{x}$ & Polygon & Woody \\
\hline poplar plantation $<1$ ha & $\mathrm{x}$ & $\mathrm{x}$ & & & & $\mathrm{x}$ & Polygon & Woody \\
\hline Short dune vegetation (>1 m) & $\mathrm{x}$ & $\mathrm{x}$ & $\mathrm{x}$ & $\mathrm{x}$ & $\mathrm{x}$ & $\mathrm{x}$ & Polygon & Herbaceous \\
\hline Tall dune vegetation $(>1 \mathrm{~m})$ & & $\mathrm{x}$ & $\mathrm{x}$ & $\mathrm{x}$ & $\mathrm{x}$ & $\mathrm{x}$ & Polygon & Woody \\
\hline Water in wetland area & & $\mathrm{x}$ & & $\mathrm{x}$ & $\mathrm{x}$ & & & \\
\hline Waterbank in agricultural surroundings & $\mathrm{x}$ & $\mathrm{x}$ & $\mathrm{x}$ & $\mathrm{x}$ & $\mathrm{x}$ & & & \\
\hline Willow plantation & & $\mathrm{x}$ & $\mathrm{x}$ & $\mathrm{x}$ & $\mathrm{x}$ & $\mathrm{x}$ & Polygon & Woody \\
\hline Willow plantation $<1$ ha & $\mathrm{x}$ & $\mathrm{x}$ & $\mathrm{x}$ & $\mathrm{x}$ & $\mathrm{x}$ & & & \\
\hline
\end{tabular}

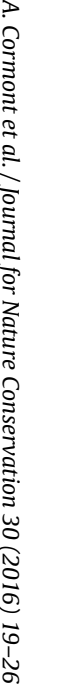



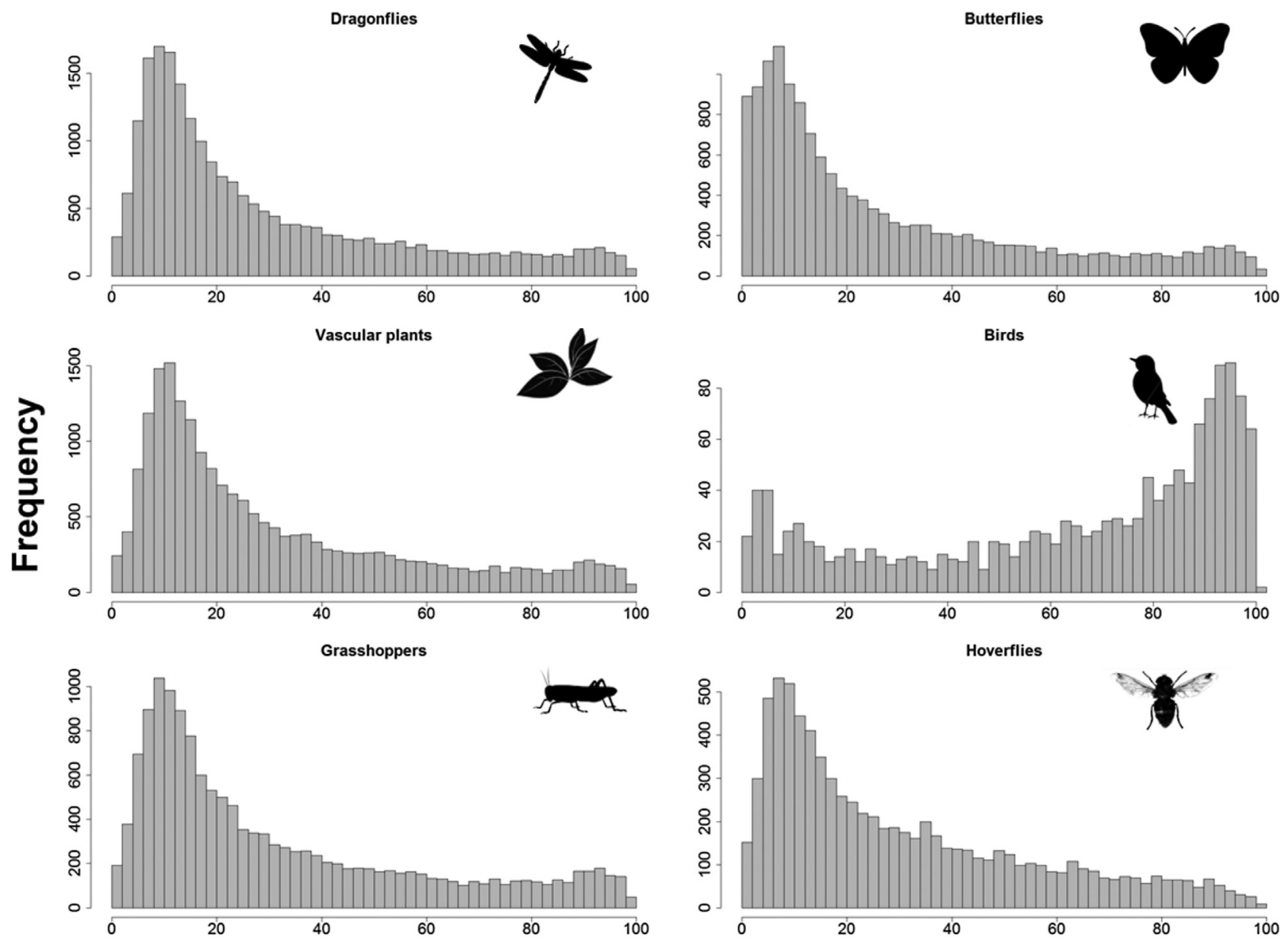

Density of natural elements (\%)

Fig. A1. Frequency distributions of density of natural elements in km squares (monitoring plots for birds).

\section{References}

Batáry, P., Báldi, A., Kleijn, D., \& Tscharntke, T. (2011). Landscape-moderated biodiversity effects of agri-environmental management: a meta-analysis. Proceedings of the Royal Society B-Biological Sciences, 278, 1894-1902.

Carvalheiro, L. G., Kunin, W. E., Keil, P., Aguirre-Gutierrez, J., Ellis, W. N., Fox, R., et al. (2013). Species richness declines and biotic homogenisation have slowed down for NW-European pollinators and plants. Ecology Letters, 16, 870-878.

Global Biodiversity Outlook 3, ed. S.o.t.C.o.B. Diversity, Montréal.

CBS. (2015). Centraal Bureau voor de Statistiek. www.cbs.nl.

Duelli, P., \& Obrist, M. K. (2003). Biodiversity indicators: the choice of values and measures. Agriculture Ecosystems \& Environment, 98, 87-98.

EC. (2010). The CAP towards 2020: meeting the food, natural resources and territorial challenges of the future. http://ec.europa.eu/agriculture/cap-post2013/communication/index_en.htm.

EC. (2013). CAP Reform-an explanation of the main elements. EC MEMO/13/621.

European Environment Agency. (2010). EU 2010 biodiversity baseline. In Tech. Rep. No. $12 / 2010$

Eurostat (2015). http://ec.europa.eu/eurostat/data/database.

Hanski, I. (2005). The shrinking world: ecological consequences of habitat loss. Oldendorf/Luhe, Germany: International Ecology Institute.

Ihaka R., Gentleman R. (1996). R package. http://cran.r-project.org.

Kleukers, R. M. J. C., Van Nieukerken, E. J., Odé, B., Willemse, L. P. M., \& Van Wingerden, W. K. R. E. (1997). De sprinkhanen en krekels van Nederland (Orthoptera). Nederlandse Fauna 1. Nationaal Natuurhistorisch Museum: KNNV-Uitgeverij \& EIS-Nederland.

MacArthur, R. H. (1965). Patterns of species diversity. Biological Reviews of the Cambridge Philosophical Society, 40, 510.

Martinez, S., Ramil, P., \& Chuvieco, E. (2010). Monitoring loss of biodiversity in cultural landscapes. New methodology based on satellite data. Landscape and Urban Planning, 94, 127-140.

Nederlandse Vereniging voor Libellenstudie. (2002). De Nederlandse libellen (Odonata) [The Dutch dragonflies (Odonata)]. Leiden, the Netherlands: Nationaal Natuurhistorisch Museum Naturalis, KNNV Uitgeverij \& European Invertebrate Survey.
Pe'er, G., Dicks, L. V., Visconti, P., Arlettaz, R., Baldi, A., Benton, T. G., et al. (2014). EU agricultural reform fails on biodiversity. Science, 344, 1090-1092.

Prendergast, J. R., Quinn, R. M., Lawton, J. H., Eversham, B. C., \& Gibbons, D. W. (1993). Rare species, the coincidence of diversity hotspots and conservation strategies. Nature, 365, 335-337.

Reemer, M., Renema, W., Van Steenis, W., Zeegers, T., Barendregt, A., Smit, J. T., et al. (2009). De Nederlandse zweefvliegen (Diptera: Syrphidae). Nederlandse Fauna, 8.

Schouten, M. A., Verweij, P. A., Barendregt, A., Kleukers, R. M. J. C., Kalkman, V. J., \& de Ruiter, P. C. (2009). Determinants of species richness patterns in the Netherlands across multiple taxonomic groups. Biodiversity and Conservation, $18,203-217$.

Shmida, A., \& Wilson, M. V. (1985). Biological determinants of species-diversity. Journal of Biogeography, 12, 1-20.

Stoate, C., Baldi, A., Beja, P., Boatman, N. D., Herzon, I., van Doorn, A., et al. (2009) Ecological impacts of early 21st century agricultural change in Europe-a review. Journal of Environmental Management, 91, 22-46.

Teillard, F., Allaire, G., Cahuzac, E., Leger, F., Maigne, E., \& Tichit, M. (2012). A novel method for mapping agricultural intensity reveals its spatial aggregation: implications for conservation policies. Agriculture Ecosystems \&' Environment, 149, 135-143.

Tscharntke, T., Clough, Y., Wanger, T. C., Jackson, L., Motzke, I., Perfecto, I., et al. (2012). Global food security, biodiversity conservation and the future of agricultural intensification. Biological Conservation, 151, 53-59.

Tscharntke, T., Tylianakis, J. M., Rand, T. A., Didham, R. K., Fahrig, L., Batáry, P., et al. (2012). Landscape moderation of biodiversity patterns and processes-eight hypotheses. Biological Reviews, 87, 661-685.

Van der Meijden, R., Groen, C. L. G., Vermeulen, J. J., Peterbroers, T., Van 't Zelfde, M., \& Witte, J. P. M. (1996). De Landelijke Floradatabank FLORBASE-1. In Eindrapport. Leiden/Wageningen, the Netherlands: RHHB/CML/UL-WHH.

Van Dijk, A. J. (2004). Handleiding Broedvogel monitoring project. Beek-Ubbergen, The Netherlands: SOVON Vogelonderzoek Nederland.

Van Strien, A. J., Termaat, T., Kalkman, V., Prins, M., De Knijf, G., Gourmand, A. L., et al. (2013). Occupancy modelling as a new approach to assess supranational 
trends using opportunistic data: a pilot study for the damselfly Calopteryx splendens. Biodiversity and Conservation, 22, 673-686.

Van Swaay, C. A. M., Nowicki, P., Settele, J., \& van Strien, A. J. (2008). Butterfly monitoring in Europe: methods, applications and perspectives. Biodiversity and Conservation, 17, 3455-3469.

Van Teeffelen, A., \& Moilanen, A. (2008). Where and how to manage: optimal selection of conservation actions for multiple species. Biodiversity Informatics, $5,1-13$.
Van Turnhout, C. A. M., Foppen, R. P. B., Leuven, R. S. E. W., Van Strien, A., \& Siepel, H. (2010). Life-history and ecological correlates of population change in Dutch breeding birds. Biological Conservation, 143, 173-181.

Whittingham, M. J., Krebs, J. R., Swetnam, R. D., Vickery, J. A., Wilson, J. D., \& Freckleton, R. P. (2007). Should conservation strategies consider spatial generality? Farmland birds show regional not national patterns of habitat associationld conservation strategies consider spatial generality? Farmland birds show regional not national patterns of habitat association. Ecol. Lett., 10, 25-35. 